\title{
Strategi Pengembangan Desa Wisata Di Desa Sidorejo Kecamatan Kendal Kabupaten Ngawi
}

\author{
Endang Murti \\ Fakultas Ilmu Sosial Dan Ilmu Politik, Universitas Merdeka Madiun, Jl. Serayu No.79, Madiun, 63133 \\ E-mail: endangmurti@unmer-madiun.ac.id
}

\begin{abstract}
The purpose of this study was to determine the strategy for developing a tourism village in Sidorejo Village, Kendal District, Ngawi Regency. Respondents or informants in this study were the Ngawi District Tourism Office, Sidorejo Village Nature Tourism Object Manager, Sidorejo Village Government Apparatus and tourists visiting the natural and earth tourism objects of Sidorejo Village. Data collection techniques used questionnaires and interviews and documentation. Data analysis techniques using SWOT analysis. The conclusion of the study shows that the strategy for developing natural attractions and camping ground in Sidorejo Village, Kendal District, Ngawi Regency includes: (1) Building infrastructure such as access roads to tourist sites that are easier to reach using private vehicles or public transportation and the roads are already physically paved. ; (2) Creating tourist attractions such as dance, music and traditional ceremonies of a local culture, both traditional and modern; (3) Promotion of tourism objects by giving free tickets to tourists; and (4) Developing tourism products by providing cafes around tourist objects and building hotels, guest houses, home stays and providing stalls for selling souvenirs in the form of traditional souvenirs and handicrafts.
\end{abstract}

Keywords—: strategy; development; tourism village.

\section{PENDAHULUAN}

Indonesia merupakan negara dengan keanekagaraman hayati berupa sumber daya alam yang berlimpah, baik di daratan, udara maupun di perairan. Sumber daya alamnya dapat meningkatkan pertumbuhan ekonomi bagi warga masyarakat apabila sumber daya tersebut di kelola dengan baik, sesuai dengan apa yang paling diminati dan bisa memberikan daya tarik bagi masyarakat luas. Sekarang ini, memberikan kesempatan kepada setiap pemerintah daerah untuk dapat mengembangkan potensipotensi yang ada di masing-masing dengan tujuan untuk menambah pendapatan asli daerah.

Pariwisata menjadi sektor unggulan bagi banyak daerah karena pariwisata dipandang menjanjikan untuk mendatangkan keuntungan bagi daerah serta penyedia lapangan kerja baru bagi masyarakat daerah.Potensi wisata yang ada di setiap daerah termasuk di Kabupaten Ngawi, merupakan peluang bagi peningkatan kepariwisataan baik dari segi kuantitas maupun segi kualitas.Dengan demikian, dapat menjaga sifat keandalan di dalam kontribusinya pada masalah peningkatan dan peran kepariwisataan terkait dengan pembangunan daerah.Dapat dimengerti, bahwa upaya pembangunan wisata perlu dilakukan secara berkesinambungan dan berkelanjutan, dengan harapan hasil pengembangan kepariwisataan tersebut dapat mempengaruhi bertambahnya jumlah kedatangan wisatawan serta memberikan kesan tidak terlupakan bagi wisatawan yang berkunjung, terhadap aset wisata yang ada.

Pembangunan pariwisata pedesaan diharapkan menjadisuatu model pembangunan pariwisata berkelanjutan sesuai dengan kebijakan pemerintah di bidang pariwisata. Pembangunan berkelanjutan diformulasikan sebagai pembangunan yang berusaha memenuhi kebutuhan hari ini tanpa mengurangi kemampuan generasi yang akan datang dalam memenuhi kebutuhan mereka.

Pembangunan dan pengembangan pariwisatayang telah dilakukan hendaknya mampu berkelanjutan dan dipertahankan di masa depan. Keberlanjutan pariwisata tidak mesti di wacanakan saja tanpa adanya suatu komitmen dari berbagai pihak untuk mempertahankan keberlanjutan alam, sosial ekonomi maupun budaya masyarakat sebagai modal dasar pariwisata.Pitana (2002) menyatakan dalam pariwisata berkelanjutan, penekanan keberlanjutan tidak cukup hanya berkelanjutan ekologis dan keberlanjutan pembangunan ekonomi, tetapi yang tidak kalah pentingnya adalah keberlanjutan kebudayaan, karena kebudayaan merupakan salah satu sumber daya yang sangat penting dalam pembangunan kepariwisataan.Implementasi dari konsep-konsep ini diaplikasikan dalam program pengembangan pariwisata pedesaan, sehingga pengembangan desa wisata tersebut harus tetap mampu menjaga kelestarian lingkungan.

Pengembangan potensi desa untuk dikemas sebagai desa wisata, tidak dapat lepas dari tiga ciri utama, yaitu : (1) lingkup pengembangan pada luasan yang dibatasi wilayah administrasi, (2) melibatkan unsur pemerintahan desa dan masyarakat sebagai pemilik dan pengelola, serta (3) berbasis pada pemanfaatan potensi, lanskap alam, dan kebudayaan setempat. Ciri lain yang melekat adalah pengembangan desa wisata adalah menghadirkan dampak yang positif bagi pendapatan masyarakat desa. Dengan demikian selain sebagai industri pariwisata, pengembangan ini juga mendukung perubahan bagi masyarakat desa terutama dalam hal peningkatan pendapat masyarakat (Miswanto dan Safaat, 2018), (Fitriani dan Wilardjo, 2017).

Desa Sidorejo Kecamatan Kendal Kabupaten Ngawi, merupakan salah satu obyek wisata yang menjadi bagian dari pengembangan pariwisata di Kabupaten Ngawi dan memiliki potensi untuk dikembangkan sebagai aset wisata yang menarik 
yaitu wisata alam dan perkebunan. Obyek Wisata alam yang terletak di Desa Sidorejo Kecamatan Kendal Kabupaten Ngawi, berjarak sekitar $52 \mathrm{~km}$ dari Pusat Kota Ngawi dan dapat ditempuh dengan kendaraan bermotor sekitar 30 menit untuk dapat sampai ke tempat tujuan.

Undang - Undang Republik Indonesia Nomor 10 Tahun 2009 Tentang Kepariwisataan, menjelaskan bahwa "pariwisata ialah berbagai macam kegiatan wisata dan didukung berbagai fasilitas serta layanan yang disediakan oleh masyarakat, pengusaha, pemerintah dan pemerintah daerah." Pariwisata adalah hal yang diminati oleh setiap individu, karena dapat menghilangkan kejenuhan, berkembangnya kreativitas dan mampu menunjang produktivitas suatu individu.

Dalam rangka meningkatkan kunjungan wisatawan, Pemerintah Kabupaten Ngawi telah menyusun suatu rencana umum yaitu menjadikan objek wisata alam dan bumi perkembahan di Desa Sidorejo satu paket destinasi kunjungan dengan obyek wisata yang lain. Kabupaten Ngawi pada tahun 2019 juga telah menganggarkan dana mencapai Rp. 3 miliar untuk membangun infrastuktur, berupa akses jalan yang menuju lokasi wisata dan saat ini sudah selesai dikerjakan,

Pemerintah Kabupaten Ngawi melalui Dinas Pariwisata terus berupaya untuk menata obyek wisata unggulan.Bukan hanya obyek wisata saja yang dibenahi, namun potensi peningkatan pendapatan dari para masyarakat yang menjual berbagai produk olahan hasil desa dan oleh-oleh khas desa tersebut yang mengais rejeki di obyek wisata juga mendapat perhatian serius.

Upaya pengembangan lain yang dilakukan Pemerintah Desa adalah dengan membentuk sebuah kelompok yang diberi nama Kelompok Sadar Wisata, kelompok ini tercetus karena adanya keterkaitan dengan Dinas Pariwisata Kabupaten Ngawi. Beberapa hal di atas, dilakukan guna menciptakan pengembangan dan penataan kepariwisataan di obyek wisata alam, perkebunan dan bumi perkembahan serta mendukung dan mengembangkan potensi yang ada di sekitarnya.

Objek wisata alam dan perkemahan di Desa Sidorejo Kecamatan Kendal Kabupaten Ngawi, mempunyai potensi yang sangat besar dalam menumbuhkan pendapatan daerah dan pendapatan masyarakat.Agar dapat lebih berdaya saing dalam menarik wisatawan, perlu dilakukan pengembangan sarana dan prasarana pariwisata.

Namun dalam kenyataannya, objek wisata di Desa Sidorejo Kecamatan Kendal Kabupaten Ngawi belum dapat menumbuhkan minat para wisatawan yang dibuktikan dengan terjadinya ketidak stabilan / fluktuatif kunjungan wisatawan dimana peningkatan kunjungan hanya terjadi di hari-hari libur saja, selebihnya selalu sepi. Hal ini tentu perlu mendapat perhatian, karena beberapa pedagang yang bermata pencaharian di objek wisata di Desa Sidorejo Kecamatan Kendal Kabupaten Ngawi bergantung pada kunjungan wisatawan.

Sepinya pengunjung ini disebabkan oleh kurangnya sarana inovasi hiburan yang bersifat edukatif, bila didukung dengan sarana edukatif diharapkan dapat menarik berbagai sekolah untuk mengajak siswanya guna melakukan study tour dan melakukan perkemahan pramuka ke objek wisata di Desa Sidorejo Kecamatan Kendal Kabupaten Ngawi. Sarana lainnya yang harus ada adalah inovasi hiburan yang sifatnya kekinian, seperti menambah spot foto yang beragam dan kreatif, hal lain yang mungkin bisa dilakukan untuk menarik wisatawan adalah dengan mengadakan event tahunan yang dapat dijadikan agenda rutin guna menumbuhkan minat berkunjung para wisatawan.

Berdasarkan latar belakang masalah di atas, masalah dalam penelitian ini dapat dirumuskan sebagai berikut: Bagaimanakah Strategi Pengembangan Desa Wisata Alam dan Bumi Perkembahan di Desa Sidorejo Kecamatan Kendal Kabupaten Ngawi? Sedangkan tujuan penelitian adalah untuk mendeskripsikan Strategi Pengembangan Desa Wisata objek wisata alam dan bumi perkemahan di Desa Sidorejo Kecamatan Kendal Kabupaten Ngawi.

Hasil penelitian ini diharapkan dapat dijadikan sebagai masukan bagi Pemerintah Kabupaten Ngawi dalam mengambil kebijakan dalam rangka meningkatkan dan memberdayakan potensi obyek wisata di Desa Sidorejo Kecamatan Kendal Kabupaten Ngawi. Bagi pihak lain, hasil penelitian ini diharapkan dapat menambah wawasan tentang strategi pengembangan desa wisata khususnya pada objek wisata di Desa Sidorejo Kecamatan Kendal Kabupaten Ngawi. Sedangkan bagi peneliti, hasil penelitian ini dapat menambah wawasan sekaligus merupakan penerapan ilmu pengetahuan khususnya terkait dengan strategi pengembangan desa wisata.

\section{METODE PENELITIAN}

\section{A. Jenis Penelitian}

Jenis Penelitian yang peneliti gunakan dalam penelitian ini adalah Deskriptif dengan pendekatan penelitian kualitatif.Penelitian ini dipilih karena untuk menyajikan data secara sistematis, faktual, dan akurat mengenai fakta - fakta yang ada dilapangan.Model Penelitian Deskriptif menurut Nana Syaodih Sukmadinata (2007:67) "Penelitian Deskriptif adalah suatu bentuk penelitian dasarditunjukan untuk mendeskripsikan atau menggambarkan fenomena-fenomena yang ada baik fenomena bersifat alamiah maupun rekayasah manusia. Penelitian ini mengkaji bentuk, aktivitas, karateristik, perubahan, hubungan kesamaan, dan perbedaan fenomena lain. Tidak memberikan perlakuan manipulasi, dan perubahan pada variabel-variabel bebas tetapi menggambarkan suatu kondisi apa adanya."

\section{B. Variabel dan Indikator Penelitian}

Identifikasi variabel dan indikator penelitian merupakan unsur yang paling penting dalam setiap penelitian, karena variabel dan indikator menunjukkan unsur-unsur yang diteliti, serta kriteria untuk mengukurnya. Menurut Suharsimi Arikunto (2013:97), bahwa: "variabel dapat disimpulkan sebagai atribut seseorang/objek yang mempunyai variasi antara satu orang dengan orang lain atau objek dengan objek lain." Pada umumnya variabel masih belum dapat dioperasionalkan, karena masih memiliki 
bangunan pengertian yang bersifat abstrak, maka agar dapat dioperasionalkan dalam penelitian perlu dipecah- pecah ke dalam indikator penelitian.Lebih lanjut dijelaskan oleh Suharsimi Arikunto (2013:97), "bahwa : memecah-mecah variabel menjadi sub variabel ini juga disebut kategorisasi, yakni memecah variabel menjadi kategorisasi-kategorisasi data yang dikumpulkan oleh peneliti, kategori-kategori ini dapat dikatakan sebagai indikator."

Dalam penelitian ini variabelnya adalah variabel tunggal yaitu Strategi Pengembangan Desa Wisata Alam dan Bumi Perkemahan Desa Sidorejo, dengan indikator: (1) Objek dan daya tarik wisata, (2) Prasarana wisata, (3) Sarana wisata, (4) Tata laksana atau Infrastruktur dan (5) Masyarakat / Lingkungan.

\section{Populasi penelitian}

Populasi dalam penelitian merupakan wilayah yang ingin diteliti oleh peneliti.Menurut Sugiyono (2011:80), "populasi adalah wilayah generalisasi yang terdiri atas subyek / obyek yang mempunyai kualitas dan karateristik tertentu yang ditetapkan oleh peneliti untuk dipelajari dan ditarik kesimpulan." Berdasarkan definisi-definisi diatas maka yang menjadi populasi penelitian adalah Dinas Pariwisata Kabupaten Ngawi, Pengelola Obyek Wisata Alam dan Perkembahan Desa Sidorejo, Perangkat Pemerintah Desa Sidorejo dan wisatawan yang berkunjung di objek wisata alam dan bumi perkembahan Desa Sidorejo.

\section{Sumber Data}

Menurut Suharsini Arikunto (2013:172), yang dimaksud dengan sumber data adalah "subyek darimana data dapat diperoleh".Dalam penelitian ini, peneliti menggunakan jenis data kualitatif dari sumber primer dan sumber sekunder. Dalam melakukansebuah penelitian tentu penulis harus mempunyai sumberinformasi dari data primer untuk dapat diteliti.Menurut Kriyantono (2010:41), "Data primer adalah data yang diperoleh oleh dari sumberdata pertama atau tangan pertama di lapangan.” Berdasarkan pendapat yang ada, peneliti menyimpulkan bahwa data primer merupakan data utama yang didapatkanlangsung dari apa yang akan diteliti.Adapun data primer yang diperlukan dalam penelitian ini adalah data-data yang diperoleh dari pemberian kuesioner. Menurut Uma Sekaran (2011:76), "Data sekunder adalah data yang mengacu pada informasi yang dikumpulkan dari sumber yang telah ada. Sumber data sekunder adalah catatan atau dokumentasi perusahaan, publikasi pemerintah, analisis industri oleh media, situs web, internet dan seterusnya."

\section{E. Teknik pengumpulan data}

Salah satu komponen yang penting dalam penelitian adalah pengumpulan data, Pengumpulan data dilakukan dengan sebuah metode untuk memperoleh data dan informasi yang dibutuhkan dalam rangka mencapai tujuan penelitian. Metode pengumpulan data adalah teknik atau cara yang dilakukan oleh peneliti untuk mengumpulkan data. Metode pengumpulan data ini dapat digunakan secara sendiri-sendiri, namun dapat pula digunakan dengan menggabungkan dua metode atau lebih.Adapun teknik-teknik pengumpulan data yang peneliti gunakan dalam penelitian adalah kuesioner dan dokumentasi.

Teknik kuesioner merupakan pengumpulan data melalui penyebaran kuesioner yang telah dipersiapkan, dan responden tinggal menentukan pilihan jawaban yang sudah ada. Teknik dokumentasi merupakan tehnik pengumpulan data melalui berbagai data tertulis/arsip yang berkaitan dengan fokus penelitian, sebagaimana dijelaskan Suharsimi Arikunto (2006:231), bahwa : "Metode dokumentasi yaitu catatan, transkip, buku, surat kabar, majalah, prasasti, notulen rapat, legger, agenda, dan sebagainya." Jadi dokumentasi adalah pengumpulan data dengan meneliti catatan-catatan penting yang sangat erat hubungannya dengan obyek penelitian.Peneliti menggunakan metode dokumentasi ini agar data-data hasil wawancara dan observasi lebih kredibel atau dapat dipercaya.

\section{F. Teknik Analisis Data}

Teknik Analisis Data adalah suatu metode atau cara untuk mengolah sebuah data menjadi informasi sehingga karakteristik data tersebut menjadi mudah untuk dipahami dan juga bermanfaat untuk menemukan solusi permasalahan, yang tertutama adalah masalah yang tentang sebuah penelitian. Atau analisis data juga bisa diartikan sebagai kegiatan yang dilakukan untuk merubah data hasil dari sebuah penelitian menjadi informasi yang nantinya bisa dipergunakan untuk mengambil sebuah kesimpulan. Selanjutnya Sugiyono (2013:56) mendefinisikan pengertian analisis data adalah proses mencari dan menyusun secara sistematis data yang diperoleh dari hasil wawancara, catatan lapangan, dan dokumentasi, dengan cara mengorganisasikan data ke dalam katagori, menjabarkan ke dalam unit-unit, melakukan sintesa, menyusun kedalam pola, memilih mana yang penting dan mana yang akan dipelajari, dan membuat kesimpulan sehingga mudah dipahami oleh sendiri maupun orang lain.

Analisa data dalam penelitian ini menggunakan Analisa SWOT.Analisis SWOT merupakan metode dalam perencanaan atau pengembangan, melalui identifikasi factor-faktor yang menjadi kekuatan (strengths), kelemahan (weaknesses), peluang (opportunities), dan hambatan (threats). Analisa SWOT tersebut kemudian dipadukan untuk menghasilkan matriks Faktor Strategi Eksternal (EFS) dan Faktor Strategi Internal (IFS) (Rangkuti,2014). 


\section{III.ANALISA DATA DAN PEMAHASAN}

\section{Analisa Data}

Berdasarkan hasil observasi wawancara maka diperoleh informasi tentang kekuatan, kelemahan, peluang dan ancaman yang dimilik oleh objek wisata alam dan bumi perkemahan Desa Sidorejo Kecamatan Kendal Kabupaten Ngawi. Kekuatan pada objek wisata timbul dari dalam objek wisata itu sendiri, seperti keindahan dan kesejukan alam di kawasan wisata yang dikelilingi pohon-pohon yang rindang. Kesejukan udara dilokasi wisata dengan banyaknya pepohonan yang tumbuh di sekitar lokasi objek wisata menjadi salah satu daya tarik dari wisataalam yang bisa dimanfaatkan oleh wisatawan untuk melepaskan lelah karena kesibukan sehari-hari.

Lokasi objek wisata yang jauh dari rasa khawatir akan keselamatan jiwa dan harta bendanya adalah suasana yang sangat didambakan oleh pengunjung objek wisata. Objek wisata alam dan bumi perkemahan Desa Sidorejo sudah termasuk salah satu objek wisata yang aman, karena tidak ada kasus pencurian, tindak kekerasan, perkelahian dan aktifitas pengamen yang kadang membuat pengunjung merasa jengkel dengan sikap yang tidak mau pergi sebelum diberi uang. Selain kekuatan, objek wisata alam dan bumi perkemahan Desa Sidorejo juga memiliki kelemahan yang harus diperhatikan.Kelemahan ini merupakan alat evaluasidalam pengembangan objek wisata. Yangmenjadi kelemahan dari objek wisata iniadalah fasilitas umum yang tidak tersedia, hal ini membuat pengunjung objek wisatamerasa tidak nyaman berada pada lokasiobjek wisata karena fasilitas umum seperti WC, mushola dan tempat ganti baju pada objek wisata air sangat dibutuhkansebagai fasilitas dasar pada objek wisatakarena fasilitas umum merupakanpenunjang kebutuhan sehari-hari manusia.

Tidak terawatnya fasilitas pada objek berdampak pada ketidaknyamananpengunjung.Belum adanya pembangunan saranadan prasarana obyek wisata alam dan bumi perkemahan Desa Sidorejo.Kekurangan ini semakin membuat pengunjung tidak merasa puasberkunjung ke lokasi objek wisata. Tidak tersedianyasarana seperti restoran/rumah makan,yang ada hanya warung sederhana yang menyediakan mie instan membuatpengunjung harus makan di tempat lainatau membawa makanan sendiri darirumah.

Keterbatasan sarana seperti hotel/penginapan membuat pengunjung tidakbisa menghabiskan waktunya lebih dari 24jam di lokasi objek wisata ini.Walaupun tidak dibangun hotel yang mewah, rumah-rumahpenduduk pun bisa dijadikanpenginapan sementara untuk pengunjung,tapi belum ada masyarakat yangmelakukan hal tersebut.Hal inidisebabkan kurangnya minat masyarakatuntuk berbisnis dibidang kuliner danpenginapan, selain kurang berminatmasyarakat setempat juga kurang paham bagaimana memanfaatkan peluang dibidang bisnis.

Transportasi khusus atau angkutanumum lainnya yang tidak ada ke lokasiobjek wisata membuat akses pengunjung ke lokasi objek wisata menjadi terhambat.Hal ini membuat kurangnya pengunjungyangdatang ke lokasi objek wisata alam dan bumi perkembahan Desa Sidorejo. Kurangnya tenaga professional dalam pengelolaan obyekwisata membuat objek wisata tidak terlalumenarik dimata pengunjung. Saat inipengelolaan diserahkan pada penduduk setempat.

Daripengamatan yang peneliti lakukan,pengelola objek wisata ini kurang terampildalam mengelola lokasi objek wisata.Halini tampak jelas dengan tidak adanya pembangunan terhadap fasilitas-fasilitasyang dibutuhkan pengunjung.Keterbatasan atraksi pada objekwisata.Objek alam dan bumi perkemahan Desa Sidorejo menjadikan objek wisata ini belum mampu menahanpengunjung untuk berlama-lama dilokasiobjek wisata.

Dilokasi obyek wisata ini pengunjung datang dan pergi setelah berfoto-foto dan berenang, sebagian besartidak memiliki keinginan untuk kembalilagi dalam waktu yang singkat.Hal inimenjadi penghalang bagi pedagang yang berada pada lokasi objek wisata.Dengansingkatnya kunjungan wisatawan makatidak ada minat wisatawan untuk belanjadilokasi objek wisata.Hal ini ditambah lagi dengan masih belum terwujudnyamasyarakat yang sadar wisata. Masyarakat pada lokasi objek wisata masih belumsepenuhnya sadar akan fungsi danmanfaat dari objek wisata. Belum seluruh masyarakat yang bisa menerima danramah terhadap pengunjung.Hal yangpaling penting disini adalah tidakbersedianya masyarakat untuk memberikan lahan yang berada disekitarobjek wisata untukdikelola pemerintah daerah untukdijadikan lahan pengembangan objekwisata alam dan bumi perkembahan Desa Sidorejo.

Selanjutnya Peluang adalah kemampuan yang dimiliki suatu daerah untuk dapat dimanfaatkan dan berkembang dimasa yang akan datang. Peluang ini bertujuan untuk memajukanobjek wisata.Peluang yangdimiliki oleh objek wisata alam dan perkembahan Desa Sidorejo pada kawasan strategis dari fungsi dan daya dukung lingkungan. Adanya rencana pemerintah daerah untuk mengembangkan obyek wisata alam di kawasan Kecamatan Kendal. Adanya Otonomi daerah memberi keleluasaan untuk mengembangkan potensi wisata, kebijakan otonomi daerah memberikan kewenangan kepada daerah untuk menggali potensi sumber daya alam yang ada. Dengan pemanfaatan kemajuan teknologiinformasi serta letak geografis.

Dari peluang maka akan muncul ancaman, ancaman berasal dari luar yang dapat mengancam pengembangan objek wisata alam dan perkemahan Desa Sidorejo. Ancaman terhadap pengembangan objek wisata ini adalah berkembangnya obyek wisata lain yang meningkatkan persaingan. Banyaknya obyek wisata di Kabupaten Ngawi dan sekitarnya yang memberikan variasi bagi pengunjung dan memacu pengembangan obyek wisata tersebut agar dapat menarik minat pengunjung.

Untuk dapat bersaing dengan obyek-obyek lain, obyek wisata alam dan perkemahan Desa Sidorejo perluinovasi-inovasi untuk menarik pengunjungyang merupakan tugas berat bagipengelola obyek, maka dibutuhkan sumber daya manusia yang handal dan berkualitas. Kerusakan lingkungan akibat pengembangan yang tidak tepat, merupakan ancaman yang disebabkan oleh manusia dan alam. Kesadaran pengunjung untuk ikut menjaga obyekmerupakan hal penting agar pengunjung satu sama 
Website : http://sosial.unmermadiun.ac.id/index.php/sosial

lainnya memperoleh kenyamanan dan menjaga keasrian obyek wisata. Dalam pengembangan pun perlu berhati-hati agar tidak merusak lingkungan.

Strategi pengembangan obyek wisataalam dan bumi perkembahan Desa Sidorejo dengan analisis dapat dilihat pada tabel berikut ini.

Tabel 1. Kekuatan (Strength-S)

\begin{tabular}{|c|l|}
\hline No. & \multicolumn{1}{c|}{ Kekuatan (Strength-S) } \\
\hline 1. & Keunikan dan keindahan objek wisata \\
\hline 2. & Sumber air panas yang melimpah \\
\hline 3. & Kondisi lingkungan yang aman dan nyaman \\
\hline 4. & Suasana yang memberikan kesan yang menyenangkan dan menentramkan \\
\hline
\end{tabular}

Faktor-faktor kekuatan tersebut merupakan faktor pendorong dalam pengembangan objek wisataalam dan bumi perkembahan Desa Sidorejo.

Tabel 2. Kelemahan (Weaknesses-W)

\begin{tabular}{|c|l|}
\hline No. & \multicolumn{1}{c|}{ Kelemahan $($ Weaknesses-W) } \\
\hline 1. & Keterbatasan biaya anggaran untuk pengembangan objek wisata \\
\hline 2. & Kurangnya sarana prasarana \\
\hline 3. & Tidak ada atraksi pendamping di objek wisata \\
\hline 4. & Tidak ada transportasi khusus menuju lokasi objek wisata \\
\hline 5. & Kurangnya perawatan terhadap objek wisata dan fasilitas yang sudah ada \\
\hline 6. & Tanah sekitar objek wisata masih milik penduduk \\
\hline
\end{tabular}

Faktor-faktor kelemahan tersebut bisa diatasi dengan merumuskan strategi pengelolaan oleh pemerintah dengan melibatkan masyarakat.

Tabel 3. Peluang (Opportunuties-O)

\begin{tabular}{|c|l|}
\hline No. & \multicolumn{1}{c|}{ Peluang (Opportunuties-O) } \\
\hline 1. & Adanya rencana pemerintah daerah untuk mengembangkan objek wisata \\
\hline 2. & Adanya otonomi daerah memberi keleluasaan untuk mengembangkan potensi wisata \\
\hline 3. & Terbukanya lapangan pekerjaan bagi masyarakat sekitar \\
\hline 4. & Paket wisata karena berdekatan dengan objek wisata lain \\
\hline 5. & Tingginya keinginan untuk berwisata dan berekreasi \\
\hline
\end{tabular}

Faktor-faktor yang menjadi peluang tersebut merupakan modal yang dapat digunakan untuk mengembangkan objek wisata alam dan bumi perkembahan Desa Sidorejo.

\begin{tabular}{|c|l|}
\hline \multicolumn{1}{|c|}{ Tabel 4. Ancaman (Threats-T) } \\
\hline No. & \multicolumn{1}{c|}{ Ancaman (Threats-T) } \\
\hline 1. & Berkembangnya obyek wisata lain meningkatkan persaingan \\
\hline 2. & $\begin{array}{l}\text { Kerusakan lingkungan akibat pengembangan objek wisata tanpa memperhatikan } \\
\text { keselamatan/kelestarian lingkungan }\end{array}$ \\
\hline 3. & $\begin{array}{l}\text { Kurangnya kesadaran masyarakat sekitar objek wisata akan pentingngya keberadaan objek } \\
\text { wisata khususnya dalam meningkatkan ekonomi masyarakat }\end{array}$ \\
\hline
\end{tabular}

Selanjutnya sesuai dengan kekuatan, kelemahan, peluang dan ancaman dapatdilakukan analisis SWOT. Strategi yang dilakukan dalam pengembangan objek wisataalam dan bumi perkembahan Desa Sidorejo sesuai analisis SWOT adalah dengan menghasilkan empat alternatif strategi yaitu alternatif Strategi SO (ciptakan strategi yang mengunakan kekuatan untuk memanfaatkan peluang), alternatif strategi WO (ciptakan strategi yang yang meminimalkan kelemahan untuk memanfaatkan peluang), alternative strategi ST (ciptakan strategi yang mengunakan kekuatan untuk mengatasi ancaman) dan alternatif strategi WT (ciptakan strategi yang meminimalkan kelemahan-kelemahan dan menghindari ancaman).

\section{A. Strategi SO (Strength and Opportunities)}

Strategi SO yaitu strategi yang mengoptimalkan kekuatan (Strenght) untuk memanfaatkan Peluang (Oportunities). Alternatif dari strategi SO (Strength and Opportunities) adalah sebagai berikut:

\section{Membangun, memperbaiki dan memelihara sarana prasarana wisata}

Setiap objek wisata yang dikujungi oleh wisatawan, tentu mereka menginginkan lokasi wisata yang menarik untuk dikunjungi, bukan hanya atraksi yang ditampilkan dari objek wisata akan tetapi sarana dan prasarana yang ada di kawasan objek wisata. Sarana prasarana kepariwisataan sangat berpengaruh terhadap meningkatnya jumlah kunjungan wisatawan datang ke objek wisata. Jika wisatawan merasa kebutuhannya selama berada di daerah objek wisata tercukupi tentu akan menjadi kenangan tersendiri bagi pengunjung, dan adanya keinginan untuk kembali ke objek wisata tersebut. Untuk itu disekitar ataupun dikawasan objek wisata perlu dibangun sarana prasarana pendukung kegiatan kepariwisataan 
guna keberlanjutan pariwisata di daerah tersebut, seperti membangun restoran, tempat penjualan souvenir, bank, puskesmas, MCK, lahan parkir, tempat pengambilan karcis, mini POM dan gazebo. Selain membangun dan mengadakansarana prasarana objek wisata,memperbaiki dan memelihara sarana dan prasarana yang sudah ada juga sangatpenting, tanpa perawatan sarana danprasarana tentu tidak akan menarikpengunjung. Pemeliharaan dilakukanuntuk mempertahankan keindahan saranayang sudah rusak sehingga bisa difungsikan lagi tanpa harus membuatyang baru dan bisa dimanfaatkan dalam jangka waktu yang panjang.

\section{Mengadakan Akomodasi Pariwisata}

Akomodasi merupakan rumah sementara untuk beristirahat apabila mereka lelah selama wisatawan berada di daerah yang ia kunjungi, baik itu hotel, losmen maupun villa dengan kenyamanandan pelayanan yang baik dan kebersihan sanitasinya. Semua fasilitas harus sesuaidengan kebutuhan wisatawan.Jumlahnyaharus diperhitungkan berdasarkan jumlah dan lamanya wisatawan tinggal di tempat objek wisata.

\section{Mengembangkan Atraksi Wisata}

Atraksi wisata yang baik harus dapat mendatangkan wisatawan sebanyak-banyaknya, menahan mereka di tempat atraksi dalam waktu yang cukup lama dan memberi kepuasan kepada wisatawan yang datang berkunjung. Atraksi wisata selain yang disediakan oleh alam perlu dibangun atraksi pendamping pariwisata agarsuasana dan keadaan objek wisata tidak membosankan. Atraksi yang bisa di bangun pada obyek wisata alam dan bumi perkemahan di Desa Sidorejo Kecamatan Kendal Kabupaten Ngawiumumnya adalah keindahan alam dan kenyamanan untuk tempat perkemahan. Atraksi pendamping yang bisa dibangun seperti, FlyingFox, tempat pemancingan, dan tempat bermain anak.

\section{Membangun dan mengadakan aksesibilitas wisata}

Aksesibilitas adalah semua faktor yang dapat memberi kemudahan kepada wisatawan untuk berkunjung ke daerah tujuan wisata seperti: seperti tersedianya prasarana jalan, jembatan, dan transportasi. Aksesibilitas merupakan prasarana yang paling penting dalam mendukung pengembangan pariwisata daerah, karena dengan akses jalan yang baik akan memberikan rasa nyaman kepada wisatawan untuk melaluinya tanpa ada rasa khawatir akan terjadinya kecelakaan.

Berdasarkan hasil interview dan survei lapangan menunjukkan bahwa jalanmenuju obyek wisata alam dan bumi perkemahan di Desa Sidorejo Kecamatan Kendal Kabupaten Ngawicukup bagus, licin dan beraspal tapi kondisi jalan semakin mendekati objek wisata jalan semakin menyempit, tentu faktor ini menjadi salah satu kelemahan bagi obyek wisata alam dan bumi perkemahan di Desa Sidorejo Kecamatan Kendal Kabupaten Ngawi. Untuk itu diperlukan strategi dengan memanfaatkan peluang yang adauntuk mengatasi kelemahan dengan memperlebar jalan yang sempit. Selainjalan yang dapat mempermudah akses, sarana transportasi juga sangat berpengaruh terhadap kenyamanan perjalanan wisatawan untuk berkunjungke daerah tujuan wisata.dengan jalan yang bagus tampa adanya transportasiperjalanan pengunjung menuju objekwisata akan terhambat.

Transportasi merupakan sarana pengangkutan yang dapat membawa wisatawan dari tempat tinggal menuju daerah lain atau tujuan wisata. Hal ini dapat dilakukan melalui udara, darat, dankapal untuk memperlancar perjalanan dengan menyediakan sarana transportasi khusus untuk mengantar wisatawan ke lokasi objek wisata maupun ke tempat-tempat lain yang berhubungan dengan aktivitasnya di daerah wisata yang dikunjungi.

Dengan menghidupkan kembali pengusaha swasta di bidang angkutan umum untuk kembali beroperasi, bekerja sama dengan dengan pihak swasta seperti travel agent, baik yang berasal di provinsi ataupun di luar dan membuat paket-paket perjalanan wisata.

\section{B. Strategi WO (Weaknesses and Opportunities)}

Strategi WO (Weaknesses and Opportunities) yaitu strategi yang meminimalkan kelemahan (Weaknesses) dengan memanfaatkan peluang (Opportunities) adalah sebagai berikut:

1. Meningkatkan promosi dan memperbaiki program pengembangan lebih bagus untuk menarik pengunjung sehingga siap untuk menghadapi persaingan antar objek wisata Promosi merupakan suatu cara atustrategi yang dilakukan oleh perusahaan untuk memperkenalkan produknya kepada khalayak ramai. Strategi meningkatkan promosi dimaksudkan untuk memanfaatkan peluang yang ada dalam mengurangi kelemahan belum berkembangnya suatu objek wisata. Salah satu promosi yang bisa dilakukan adalah memanfaatkan even-even pariwisata yang dirancang oleh pemerintah Kabupaten Ngawi sebagai sarana promosi dan pengenalan objek wisata alam dan bumi perkemahan kepada masyarakat dalam negeri. Promosi dapat dilakukan melalui media elektronik, surat kabar, spanduk dan pamplet.

2. Melakukan koordinasi dengan pihak swasta untuk menanamkan modal

Strategi ini dilakukan dengan tujuan untuk mendukung kelanjutan pembangunan agar dapat membantu membangun sarana prasarana, akomodasi, atraksi objek wisata pendamping dan sarana lainnya yang belum disediakan secara professional. Maka untuk itu diperlukan koordinasi guna menarik minat investor atau pihak swasta dan pemerintah. Koordinasi dengan pihak swasta untuk menanamkan modalnya. Dengan membentuk ikatan kerja sama atas dasar kesepakatan dan rasa saling membutuhkan dalam rangka meningkatkan kapabilitas di suatu bidang usaha tertentu.

3. Melakukan pemberdayaan, penyuluhan agar menumbuhkan dan meningkatkan kesadaran masyarakat tentang pentingnya masyarakat Sadar Wisata. Masyarakat Sadar Wisata merupakan masyarakat yang secara sadar dan bertanggung jawab 
Website : http://sosial.unmermadiun.ac.id/index.php/sosial

berperan serta dalam mencapai sasaran pengembangan pariwisata dengan menggalang sikap dan tingkah laku sebagai tuan rumah dengan menerapkan sapta pesona dalam kehidupan sehari-hari. Sapta pesona yakni kondisi atau tujuh unsur yang dapat meningkatkan daya pariwisata.

\section{Strategi ST (Strength and Treats)}

Strategi ST (Strength and Treats) yaitustrategi yang mengunakan kekuatan(Strength) untuk mengatasi ancaman (Treats) adalah:

4. Mengoptimalkan potensi alam dan keunikan objek wisata dengan mempertahankan dan pemeliharaan objek wisata secara berkesinambungan untuk menghadapi persaingan antar objekwisata.

5. Pengembangan dan pembangunan objek wisata yang ramah lingkungan dengan melakukan kontrol yang tegas terhadap pelaksanaan unsur-unsur pelakuwisata yang tidak sesuai dengansikap dan tindakan pelaku wisata yang dapat mengancam kerusakan objek wisata.

6. Mengadakan objek wisata pendamping. Objek wisata pendamping sangat penting agar suasana pada objek wisata memiliki variasidan mampu menarik dan mempertahankan wisatawan untukberlama-lama dilokasi objek wisata alam dan perkemahan.

\section{Strategi WT (Weaknesses and Treats)}

Strategi WT (Weaknesses and Treats) yaitu strategi yang meminimalkankelemahan (Weaknesses) dan menghindari ancaman

(Treats) adalah sebagai berikut:

1. Peningkatan kualitas tenaga kerja professional dalam pengelolaan dan pemeliharaan objek wisata secara ber-kesinambungan sehingga mengurangi kerusakan lingkungan akibat pengembangan yang seenaknya.

2. Melakukan pengawasan dan pemeliharaan fasilitas-fasilitas yang telah ada dilokasi objek wisata.

\section{IV.KESIMPULAN}

Berdasarkan hasil penelitian maka dapat disimpulkan hasil penelitian sebagai berikut:

1. Strategi pengembangan objek wisata alam dan bumi perkemahan Desa Sidorejo Kecamatan Kendal Kabupaten Ngawi antara lain:

a. Membangun sarana prasarana seperti akses jalan menuju ke lokasi wisata lebih mudah dijangkau dengan menggunakan kendaraan pribadi maupun kendaraan umum dan sudah secara fisik jalannya sudah diaspal .

b. Membuat atraksi wisata seperti tari, musik dan upacara adat suatu budaya setempat baik tradisional maupun modern.

c. Promosi obyek wisata dengan memberikan tiket gratis kepada wisatawan pada even tertentu.

d. Mengembangkan produk wisata dengan disediakan cafe-cafe di sekitar obyek wisata dan dibangun guest house, home stay serta disediakan kios-kios tempat penjualan buah tangan berupa oleh-oleh tradisional dan hasil kerajinan tangan.

2. Seluruh kekuatan dan peluang yang dimiliki apabila secara terus menerus ditingkatkan dengan meminimalkan kelemahan seperti mengelola obyek wisata sesuai dengan manajemen modern, obyek wisata selalu di renovasi sesuai dengan perkembangan jaman, sehingga terjadi peningkatan wisatawan atau pengunjung. Hal ini dilakukan untuk menghindari dari segi ancaman, atau pesaing yang juga mendirikan obyek wisata yang sama. Dengan didukung oleh penerapan strategi pengembangan yang tepat maka obyek wisata alam dan bumi perkemahan di Desa Sidorejo Kecamatan Kendal Kabupaten Ngawi akan mampu bersaing dengan objek wisata lainnya yang ada di Kabupaten Ngawi.

\section{UCAPAN TERIMAKASIH}

Ucapan terima kasih disampaikan kepada Pemerintah Kabupaten Ngawi dalam hal ini Kepala Dinas Pariwisata dan Kepala Desa Sidorejo yang telah memberikan ijin dan membantu penulis pada saat melaksanakan penelitian. Kepada rekan-rekan dosen Universitas Merdeka Madiun yang telah memberikan kontribusi dan saran guna penyempurnaan jurnal penelitian serta Rektor Universitas Merdeka Madiun yang telah memberikan bantuan pendaan dalam kegiatan penelitian.

\section{VI.DAFTAR PUSTAKA}

Atmoko, T. Prasetyo Hadi. 2014. Strategi Pengembangan Potensi Desa Wisata Brajan Kabupaten Sleman. Jurnal Media Wisata Volume 12, Nomor 2 , November 2014.

Chandler, 1962. Strategy and Structure: Chapters in the History of The Industrial Enterprise, Beard Books.

David, F.R, 2011. Strategic Management Manajemen Strategi Konsep, Edisi 12, Jakarta: Salemba Empat.

Irhandayaningsih, Anna. 2019. Strategi Pengembangan Desa Gemawang sebagai Desa Wisata Eko Budaya. ANUVA Volume 3 (3):283-290, 2019.

http://ejournal.undip.ac.id/index.php/anuva

Oka A. Yoeti, 2005. Perencanaan Strategis Pemasaran Daerah Tujuan Wisata, Jakarta: Pradnya Paramita.

Rangkuti, Freddy, 2014. Analisis SWOT: Teknik Membedah Kasus Bisnis, Jakarta: PT Gramedia Pustaka Utama

Republik Indonesia. 2009. Undang-Undang Republik Indonesia Nomor 10 Tahun 2009 tentang Kepariwisataan.

Sekaran, Uma. 2011. Research Methods for Businness Edisi I and 2, Jakarta: Salemba Empat.

Sugiyono. 2007. Metode Penelitian Administrasi, Bandung: Alfabeta.

Suharsimin Arikunto, 2013.Prosedur Penelitian Suatu Pendekatan Praktik. Jakarta: Rineka Cipta.

Sukmadinata, 2007. Metode Penelitian Pendidikan, Bandung: Remaja Rosdakarya.

Sutrisno Hadi. 1988. Statistika Jilid I, Yogyakarta: Fakultas Psikologi UGM. 
Website : http://sosial.unmermadiun.ac.id/index.php/sosial

Wiwiek Rabiatul Adawiyah, Agung Praptapa, Mafudi Mafudi. 2017. Strategi Pengembangan Desa Wisata Berbasis Masyarakat (Community Based Rural Tourism) di Desa Papringan.Prosiding Seminar Nasional dan Call for Papers "Pengembangan Sumber Daya Perdesaan dan Kearifan Lokal Berkelanjutan VII" 17-18 November 2017 Purwokerto. 